\title{
Landau-Kleffners syndrom
}

\author{
Landau-Kleffners syndrom er en sjelden epileptisk encefalopati med \\ debut i barneårene. Man bør mistenke tilstanden dersom et normalt \\ utviklet barn nokså plutselig mister etablerte språkferdigheter. Barna \\ bør henvises til den regionale barneavdelingen eller til Spesialsykehuset \\ for epilepsi for en bredt anlagt tverrfaglig utredning. En EEG-under- \\ søkelse under våkenhet og søvn er avgjørende for å stille diagnosen.
}

Landau-Kleffners syndrom er en epileptisk encefalopati som vanligvis oppstår hos normalt utviklede barn i 3-8 års alder (1). Hovedsymptomene er en akutt eller subakutt språkforstyrrelse med manglende evne til å gjenkjenne, bearbeide eller tolke språklige og/eller ikke-språklige lyder (1). Nattlig epileptisk aktivitet hindrer tilgang til barnets tidligere etablerte impressive og ekspressive språk (1). Prognosen for språkforstyrrelsene varierer. En liten norsk studie der 11 pasienter ble fulgt i over ti år viste at ca. $1 / 3$ får en normal eller tilnærmet normal språkfunksjon, ca. $1 / 3$ făr moderate vedvarende språkvansker, mens ca. $1 / 3$ ender opp med et ikkefunksjonelt språk, verken reseptivt eller ekspressivt (2). I ICD-10 benyttes terminologien Landau-Kleffners syndrom eller Ervervet afasi med epilepsi (F80.3).

I motsetning til andre epileptiske encefalopatier i barneårene, for eksempel Lennox-Gastauts syndrom, er Landau-Kleffners syndrom fremkalt av en aldersavhengig epileptisk aktivitet i hjernen som opptrer primært i de dype søvnstadiene. Tilstanden tilhører et spekter av beslektede forstyrrelser, inkludert godartet barneepilepsi med sentrotemporale spikes (benign childhood epilepsy with centrotemporal spikes, BECTS) og kontinuerlig nattlig epileptisk aktivitet (continuous spikes and waves during slow-wave sleep, CSWS) (1).

\section{Epidemiologi}

Landau \& Kleffner beskrev i 1957 seks barn med denne tilstanden (3). Siden har det på verdensbasis vært beskrevet mer enn 350 barn med dette syndromet, og i Norge er det ved Nasjonalt kompetansesenter for sjeldne epilepsirelaterte diagnoser registrert 28 personer med denne diagnosen i 2015. Den sanne insidensen og prevalensen er ikke kjent. Gutter rammes hyppigere enn jenter. Alder ved sykdomsdebut er vanligvis 3-8 år, men det er beskrevet debut ned til to år og så sent som 14 år (4).

\section{Etiologi og basale mekanismer}

Årsaken til Landau-Kleffners syndrom er ukjent. Bildediagnostikk av hjernen viser som regel normale funn. Man har ingen sikker genetisk forklaring, men det er beskrevet familier med mutasjoner i GRIN2A-genet der noen medlemmer har Landau-Kleffners syndrom, mens andre har godartet barneepilepsi med sentrotemporale spikes eller kontinuerlig nattlig epileptisk aktivitet (5).

Landau-Kleffners syndrom er definert som en epileptisk encefalopati. Dette innebærer at den epileptiske aktiviteten i seg selv forårsaker språksvikten, helt eller delvis. Fordi steroider er vist å ha svært god effekt hos en del av barna (6) samtidig som andre ikke responderer, er det nærliggende å tenke at autoimmune eller inflammatoriske prosesser kan være involvert i patogenesen hos en andel.

Flere studier viser økt mengde autoantistoffer rettet mot hjernederivert nevrotrofisk faktor (brain-derived neurotrophic factor, BDNF) hos pasienter med Landau-Kleffners syndrom sammenliknet med friske kontrollpersoner. En studie av barn med LandauKleffners syndrom viste autoimmun reaksjon mot sentralt og perifert myelin under episoder med symptomforverring. Autoantistoffer mot andre stoffer $\mathrm{i}$ hjernen er påvist $\mathrm{i}$ et begrenset antall pasienter med kontinuerlig nattlig epileptisk aktivitet (6). Behandling med intravenøs immunglobulin har hos enkelte hatt klinisk effekt samt gitt reduksjon av tidligere forhøyet IgG i spinalvæsken. Etter vår tolkning styrker dette hypotesen om at antistoffer kan være involvert (6).

På den annen side kan hissig epileptisk aktivitet i seg selv aktivere inflammatoriske prosesser som dempes av steroidbehandling. Effekt av steroider er følgelig ikke ensbetydende med en autoimmun genese (7). Den variable effekten av steroider hos disse barna kan tyde på at det kan være flere tilgrunnliggende årsaker til den epileptiforme aktiviteten.

Det gjøres ikke rutinemessig søk etter nevroantistoffer i spinalvæsken før oppstart med steroider hos barn med Landau-Kleffners syndrom. Ved Spesialsykehuset for epilepsi (SSE) har man valgt å ta nevroantistoffer i serum før oppstart. Internasjonalt er det imidlertid ingen konsensus om dette.

\author{
Mia Tuft \\ mia.tuft@ous.hf.no \\ Marte Årva \\ Nasjonalt kompetansesenter for sjeldne \\ epilepsirelaterte diagnoser \\ Marit Bjørnvold \\ John Aage Wilson \\ Karl 0. Nakken \\ Avdeling for kompleks epilepsi \\ Oslo universitetssykehus
}

Tl

Engelsk oversettelse på www.tidsskriftet.no

\section{HOVEDBUDSKAP}

Landau-Kleffners syndrom er en sjelden epileptisk encefalopati som vanligvis rammer normalt utviklede barn i 3-8 års alder

Hovedsymptomet er akutt eller subakutt tap av språklige ferdigheter

Språkforstyrrelsene skyldes epileptisk aktivitet i hjernens språkområder, særlig uttalt under dyp søvn 


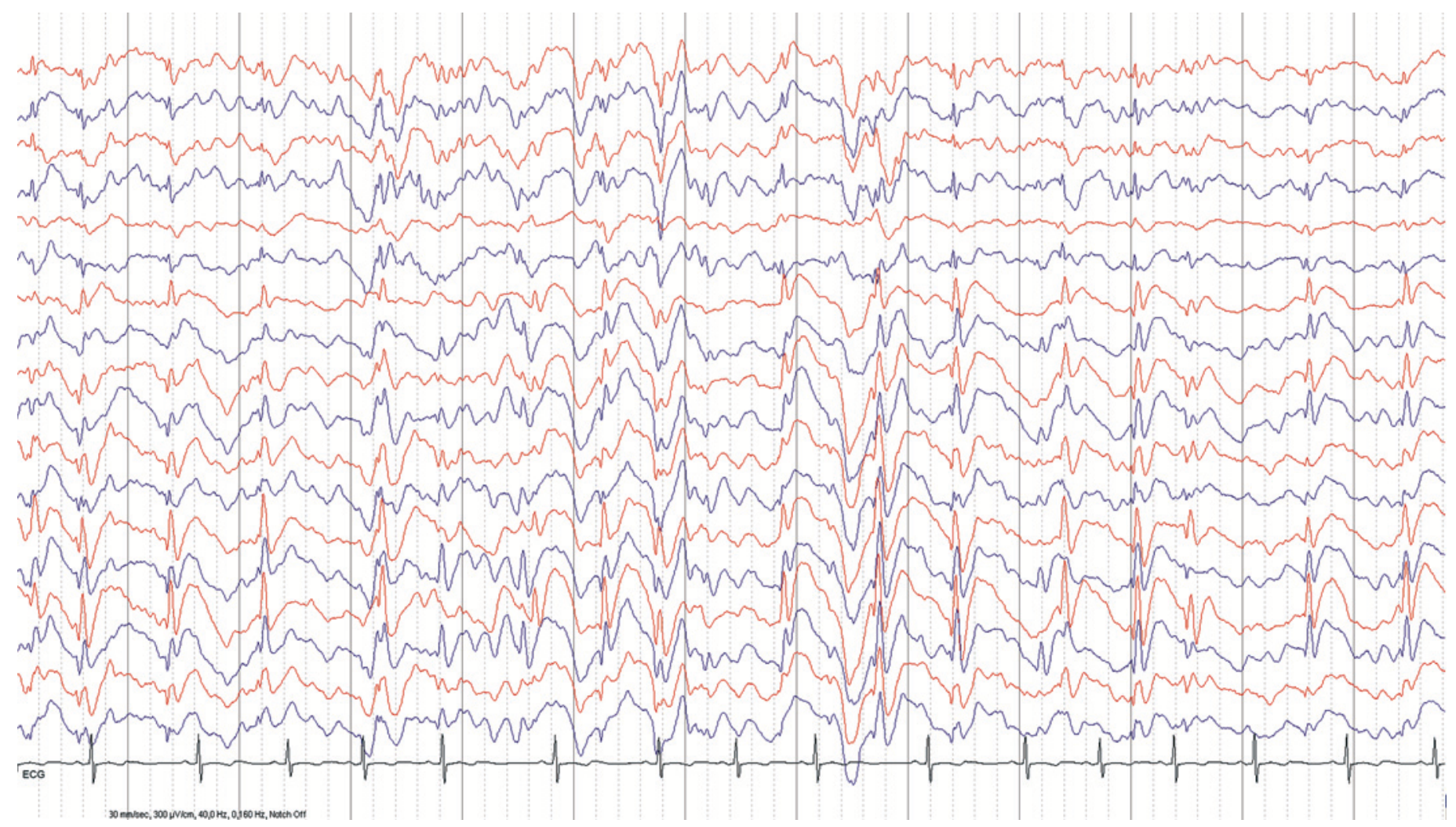

Figur 1 EEG tatt under ikke-REM-søvn. Det er intens økning av den epileptiske aktiviteten, med venstresidig dominans (rødt)

Språkproblemene forårsakes av epileptiforme forstyrrelser lokalisert til områdene omkring fissura Sylvii, dvs. områder av betydning for språkbearbeiding $(8,9)$. Når slike forstyrrelser opptrer $i$ en periode av hjernens utvikling der det foregår en livlig kortikal synaptogenese og etablering av varige funksjonelle nettverk, har man spekulert på om man kan få en abnorm synaptogenese i disse områdene med varige språkvansker som konsekvens (4).

\section{Klinisk presentasjon}

Landau-Kleffners syndrom bør mistenkes hos alle normalt utviklede barn som i $2-14$ års alder nokså plutselig mister språklige ferdigheter. De utvikler i løpet av dager, uker eller måneder en verbal og/eller auditiv agnosi, dvs. de har helt eller delvis manglende evne til å gjenkjenne, bearbeide og tolke språklige og/eller ikke-språklige lyder. Den perifere hørselen er normal, men barnet forstår ikke hva det hører. Dette påvirker barnets språkforståelse. Den muntlige fremstillingsevnen svekkes også. Typisk er artikulasjonsvansker, babling, neologismer, verbal perseverasjon, taleflyts- og ordmobiliseringsvansker eller stumhet. Rundt $10 \%$ har primært ekspressive vansker, men det mest vanlige er en kombinasjon av impressive og ekspressive vansker (8). Den individuelle variasjonen i språkfunksjonen er stor.
Denne varierer ofte over tid og synes å være uavhengig av anfallstendensen. Barn med Landau-Kleffners syndrom uten anfall kan ha store språkforstyrrelser, noe som indikerer at det er den epileptiske aktiviteten og ikke anfallene som bidrar til språkvanskene. Mange er lydvare $(2,8)$.

Hos $70-80 \%$ opptrer epileptiske anfall av forskjellig type: absenser, fokale anfall eller generaliserte tonisk-kloniske anfall (8). Anfallsfrekvensen er som regel lav. EEGforstyrrelsene er vanligvis mest uttalt over bakre temporalregioner, rundt fissura Sylvii, på den ene eller begge sider (9).

Under ikke-REM-søvn kan aktiviteten arte seg som nærmest kontinuerlig «spike wave»mønster, vanligvis med en frekvens på 1,5-2,5 per sekund (fig 1). Graden av EEGfunn avhenger av sykdomsutviklingen og er på det mest intense rundt sykdomsdebuten. Bakgrunnsaktiviteten og søvnmakroarkitekturen er vanligvis normal. Under REM-søvn opphører helt eller delvis den epileptiske aktiviteten. Standard EEG kan også være normalt.

Svak oppmerksomhetsevne, redusert impulskontroll, hyperaktivitet, aggresjon, sosial tilbaketrekking, emosjonell labilitet, angst og depresjon er relativt vanlige tilleggsvansker. Det samme er søvnforstyrrelser. Arbeidshukommelsen er som oftest svekket, mens langtidshukommelsen er intakt (8).
Man kan mistenke AD/HD og atferdsforstyrrelser hos disse barna før man blir oppmerksom på de språklige vanskene. Sannsynligvis er det flere årsaker til den utfordrende atferden, men det er nærliggende å tro at språkproblemene er hovedårsaken. En del barn med Landau-Kleffners syndrom har autismeliknende vansker (8).

Landau-Kleffners syndrom er en klinisk diagnose som fordrer en tverrfaglig utredning med grundig anamnese, nevrologiske, logopediske, nevropsykologiske og EEGundersøkelser.

\section{Differensialdiagnoser}

Kontinuerlig nattlig epileptisk aktivitet I 1971 ble det beskrevet barn med et karakteristisk EEG-bilde under søvn: elektrisk status epilepticus i søvn (electrical status epilepticus induced by sleep, ESES) (10). Det kliniske korrelatet til ESES er dårlig definert, men mange av disse barna utvikler språk- og lærevansker, kognitiv svikt og atferdsproblemer. De fleste har i tillegg epileptiske anfall av forskjellig type. Syndromet fikk i 1985 navnet kontinuerlig nattlig epileptisk aktivitet (continuous spikes and waves during slow-wave sleep, CSWS) (11). Denne tilstanden skiller seg fra Landau-Kleffners syndrom ved at de epileptiske forstyrrelsene i EEG er lokalisert mer frontalt og innebærer ofte mer generelle kogni- 
tive vansker (1). Noen av barna med tilstanden har dessuten et påvisbart morfologisk substrat i hjernen, for eksempel polymikrogyri. Rundt $0,5 \%$ av alle barn med epileptiske anfall har kontinuerlig nattlig epileptisk aktivitet.

\section{Utviklingshemning}

En forutsetning for diagnosen LandauKleffners syndrom er ifølge ICD-10 normal premorbid generell intelligens. Vi stiller oss spørrende til om dette kriteriet burde revideres. Ved forsinket diagnostikk, behandling og pedagogisk-psykologisk tilrettelegging kan barnet ende opp med svekkede kognitive evner. I sjeldne tilfeller blir det derfor riktig å stille diagnosen selv om barnet har en lett utviklingshemning. Det er dessuten ikke noe som tilsier at denne tilstanden bare rammer barn med normal intelligens. Hos barn med tidlig sykdomsdebut kan det være vanskelig å vurdere premorbid språklig og kognitiv utvikling. Det er ikke lett for nærpersoner å huske barnets språkutvikling ved å se tilbake i tid.

\section{Autismespekterforstyrrelser}

Barn med Landau-Kleffners syndrom kan mistolkes å ha autismespekterforstyrrelser, oftest infantil autisme eller regredierende former. Som ved Landau-Kleffners syndrom får barna med regredierende former for autisme tap av ervervede språklige og sosiale funksjoner. Regresjonen er ved autismespekterforstyrrelser gjerne mer generell, med kognitive vansker innen flere områder. Vansker med hvordan språk anvendes i sosiale sammenhenger er også mer uttalt. Mange av disse barna har epileptisk aktivitet i EEG (12).

\section{Andre tilstander med språkproblemer}

Alle typer ervervet afasi (for eksempelvis forårsaket av cerebrale skader, svulster eller infeksjoner), mutisme, lærevansker og hørselstap er andre aktuelle differensialdiagnoser (13).

\section{Behandling}

Det er ingen internasjonal konsensus når det gjelder behandling av Landau-Kleffners syndrom. Rask oppstart av medikamentell behandling har vist seg å være viktig for prognosen (9). Lang varighet av epileptisk aktivitet forverrer prognosen og ser ut til å ha større betydning enn alder ved sykdomsdebut (9). Målet med behandlingen er primært å normalisere språkforstyrrelsene, samt oppnå anfallsfrihet. Anfallene er gjerne milde, sjeldne og responderer som oftest godt på antiepileptika. Den epileptiske aktiviteten i EEG og språkforstyrrelsene har imidlertid tendens til å vedvare (9).

Av antiepileptika er valproat, klobazam (ev. andre benzodiazepiner), levetiracetam, etosuksimid og sultiam hyppigst benyttet (14). Etosuksimid og sultiam er ikke registrert i Norge. Hvis den epileptiske aktiviteten og språkproblemene ikke bedres med antiepileptika i løpet av få uker, anbefales oppstart med steroider (9).

Ved Spesialsykehuset for epilepsi behandles pasientene med prednisolon per os $2 \mathrm{mg} / \mathrm{kg} / \mathrm{dag}$ i minst tre måneder før en gradvis nedtrapping. Noen har behov for behandling over lengre tid. Avveiningen mellom effekten av steroidbehandlingen og uheldige langtidsbivirkninger kan være vanskelig. Ved residiv kan gjentatt prednisolonbehandling forsøkes.

Intravenøs immunglobulinbehandling har vært forsøkt med varierende resultater (14). Slik behandling kan likevel vurderes hos pasienter som ikke responderer på antiepileptika eller steroider, eller dersom språkproblemene residiverer ved nedtrapping av steroider.

Kirurgi i form av multiple subpiale transeksjoner har vært gjennomført hos et begrenset antall av de alvorligst rammede barna. Det beskrives bedring i enkelttilfeller (15). Kirurgen overskjærer de horisontale kortikokortikale fibrene, mens de vertikale kortikosubkortikale fibrene bevares. Hensikten er å hindre spredning av epileptiform aktivitet (15).

Hos barn med Landau-Kleffners syndrom som også har $\mathrm{AD} / \mathrm{HD}$ kan sentralstimulerende legemidler være aktuelt.

Helt avgjørende for barnets relasjon til omgivelsene, atferd og psykososiale fungering er å opprettholde kommunikasjon. Dette fordrer at tiltak i form av alternativ og supplerende kommunikasjon igangsettes tidlig. Visualisert språk (tegnspråk eller norsk med tegnstøtte) eller andre former for alternativ kommunikasjon med samtidig lyttetrening kan bidra positivt til intellektuell stimulering (16). Språktiltakenes virkning bør kontinuerlig evalueres og justeres fordi situasjonen raskt kan endre seg. Språklig bedring $\mathrm{i}$ tenårene gjør det nødvendig med andre tiltak, for eksempel med mer muntlig språktrening. Forsterket språkstimulering bør igangsettes når EEG bedres. Behandling og tiltak bør også rettes mot tilleggsvanskene.

\section{Prognose}

Epilepsien ved Landau-Kleffners syndrom har god prognose. De fleste blir anfallsfrie med antiepileptika. Både de epileptiske forstyrrelsene i EEG og anfallstendensen avtar eller forsvinner som regel innen 15 års alder. Den generelle intelligensen er som oftest bevart.

Prognosen for språkforstyrrelsene varierer. Fra ungdomsårene oppnår noen en normal eller tilnærmet normal språkfunksjon, noen får moderate vedvarende språkvansker, mens andre ender opp med et ikke-funksjonelt språk, både reseptivt og ekspressivt (2). For den sistnevnte gruppen er det viktig å etablere supplerende og alternative kommunikasjonsmåter så tidlig som mulig.

Tidlig debutalder og lang varighet av den epileptiforme EEG-aktiviteten er dårlige prognostiske faktorer. Fluktuasjoner i sykdomsforløpet indikerer en bedre prognose (7).

\section{Mia Tuft (f. 1972)}

er spesialist i nevropsykologi.

Forfatter har fylt ut ICMJE-skjemaet og oppgir ingen interessekonflikter.

\section{Marte Årva (f. 1971)}

er spesialpedagog.

Forfatter har fylt ut ICMJE-skjemaet og oppgir ingen interessekonflikter.

\section{Marit Bjørnvold (f. 1963)}

er dr.med., spesialist i barnesykdommer, med spesialkompetanse innen epileptologi, og er overlege.

Forfatter har fylt ut ICMJE-skjemaet og oppgir følgende interessekonflikter: Hun er nasjonal koordinator for en multisenterstudie i regi av Novartis.

\section{John Aage Wilson (f. 1949)}

er spesialist i nevrologi og i klinisk nevrofysiologi, med spesiell interesse for problemstillinger relatert til interaksjonene mellom epilepsi og søvn. Han er overlege.

Forfatter har fylt ut ICMJE-skjemaet og oppgir ingen interessekonflikter.

\section{Karl 0. Nakken (f. 1945)}

er dr.med., spesialist i nevrologi, med spesialkompetanse innen epileptologi. Han er overlege og medisinsk ansvarlig.

Forfatter har fylt ut ICMJE-skjemaet og oppgir følgende interessekonflikter: Han har mottatt forelesningshonorar fra GlaxoSmithKline, UCB og Eisai.

\section{Litteratur}

1. Smith MC, Hoeppner TJ. Epileptic encephalopathy of late childhood: Landau-Kleffner syndrome and the syndrome of continuous spikes and waves during slow-wave sleep. J Clin Neurophysiol 2003; 20: $462-72$

2. Cockerell I, Bølling G, Nakken KO. Landau-Kleffner syndrome in Norway: long-term prognosis and experiences with the health services and educational systems. Epilepsy Behav 2011; 21: 153-9.

3. Landau WM, Kleffner FR. Syndrome of acquired aphasia with convulsive disorder in children. Neurology 1957; 7: 523-30.

4. Caraballo RH, Cejas N, Chamorro N et al. LandauKleffner syndrome: a study of 29 patients. Seizure 2014; 23: 98-104. 
5. Lesca G, Rudolf G, Bruneau N et al. GRIN2A mutations in acquired epileptic aphasia and related childhood focal epilepsies and encephalopathies with speech and language dysfunction. Nat Genet 2013; 45: 1061-6.

6. Granata T, Cross H, Theodore W et al. Immunemediated epilepsies. Epilepsia 2011; 52 (suppl 3): 5-11.

7. Shimada T, Takemiya T, Sugiura H et al. Role of inflammatory mediators in the pathogenesis of epilepsy. Mediators Inflamm 2014; 2014: 901902

8. Stefanatos G. Changing perspectives on LandauKleffner syndrome. Clin Neuropsychol 2011; 25: 963-88.

9. Hughes JR. A review of the relationships between Landau-Kleffner syndrome, electrical status epilepticus during sleep, and continuous spike-waves during sleep. Epilepsy Behav 2011; 20: 247-53.

10. Patry G, Lyagoubi S, Tassinari CA. Subclinical «electrical status epilepticus» induced by sleep in children. A clinical and electroencephalographic
study of six cases. Arch Neurol 1971; 24: 242-52.

11. Tassinari CA, Rubboli G, Volpi L et al. Encephalopathy with electrical status epilepticus during slow sleep or ESES syndrome including the acquired aphasia. Clin Neurophysiol 2000; 111 (suppl 2): S94-102.

12. Chez MG, Chang M, Krasne V et al. Frequency of epileptiform EEG abnormalities in a sequential screening of autistic patients with no known clinical epilepsy from 1996 to 2005. Epilepsy Behav 2006; 8: 267-71.

13. Deonna T, Roulet-Perez E. Early-onset acquired epileptic aphasia (Landau-Kleffner syndrome,

LKS) and regressive autistic disorders with epileptic EEG abnormalities: the continuing debate. Brain Dev 2010; 32: 746-52.

14. Arts WF, Aarsen FK, Scheltens-de Boer M et al. Landau-Kleffner syndrome and CSWS syndrome: treatment with intravenous immunoglobulins. Epilepsia 2009; 50 (suppl 7): 55-8.

15. Cross JH, Neville BG. The surgical treatment of Landau-Kleffner syndrome. Epilepsia 2009; 50 (suppl 7): $63-7$.

16. Deonna T, Prelaz-Girod AC, Mayor-Dubois C et al. Sign language in Landau-Kleffner syndrome. Epilepsia 2009; 50 (suppl 7): 77-82.

Mottatt 4.2. 2015, første revisjon innsendt 8.6.

2015, godkjent 14.10. 2015. Redaktør: Tor Rosness. 